\title{
Что стоит за цифровым налогом: вызовы борьбы Европейского союза за технологический суверенитет ${ }^{1}$
}

\author{
Н. Билотта
}

Билотта Никола - исследователь Института международных отношений (Istituto Affari Internazionali (IAI)); Италия, Рим, ул. Анджело Брунетти, д. 9; E-mail: n.bilotta@iai.it

Пандемия COVID-19 показала, насколько важны цифровые платформы для функционирования нашей экономики. Крупные технологические компании, вероятно, станут сильнее после этой пандемии из-за значительного роста спроса на государственные, розничные и корпоративные цифровые услуги. Эта мегатенденция укрепила доминирующее положение цифровых транснациональных корпораций - почти все они из США - на рынках ЕС, подняв важные вопросы, начиная от стремления Европейского союза (ЕС) $\kappa$ технологическому суверенитету и заканчивая гораздо более насущным вопросом о том, как осуществлять налогообложение прибыли крупных технологических компаний. Проблема «цифрового налога», ставшая предметом оживленных международных дискуссий еще до пандемии COVID-19, сейчас обсуждается еще активнее, поскольку этот налог станет важным инструментом для правительств, остро нуждающихся в средствах финансирования постпандемического восстановления экономики. Ожидается, что с включением цифрового налога в фонд для восстановления после пандемии «Следующее поколение ЕС», представленный Еврокомиссией, ЕС еще больше укрепит свое мировое лидерство в области технологического регулирования. Однако европейская активность в сфере регулирования также может создать барьеры для трансатлантической торговли и инвестиций, что приведет к росту напряженности в отношениях $c$ США.

Ключевые слова: цифровое управление; налогообложение; Европейский союз; США; трансатлантические отношения; коронавирус

Для цитирования: Билотта Н. (2020) Что стоит за цифровым налогом: вызовы борьбы Европейского союза за технологический суверенитет // Вестник международных организаций. Т. 15. № 4. С. 30-47 (на русском языке). DOI: 10.17323/1996-7845-2020-04-02

\section{Введение}

Пандемия COVID-19 подорвала мировую экономику, вызвав более глубокий кризис, чем Великая рецессия 2008-2009 гг. На мировых рынках в результате кризиса оказалось много проигравших и очень мало победителей. Среди последних особенно хорошо проявили себя крупные компании технологической сферы. Благодаря резкому росту государственного и частного (как розничного, так и корпоративного) спроса на циф-

${ }^{1}$ Bilotta N. Beyond the Digital Tax: The Challenges of the EU's Scramble for Technological Sovereignty / Istituto Affari Internazionali (IAI). Статья с разрешения автора переведена А.В. Шелеповым, к.э.н., с.н.с. Центра исследований международных институтов Российской академии народного хозяйства и государственной службы при Президенте Российской Федерации (РАНХиГС). 
ровые услуги, а также ожиданиям дальнейших инвестиций в цифровизацию цепочек создания стоимости, цифровые транснациональные корпорации, такие как Amazon, вероятно, станут после пандемии сильнее, чем раньше.

В Европейском союзе (ЕС) перспективы получения огромных прибылей крупными технологическими компаниями возродили горячие дискуссии о так называемом цифровом налоге, специально разработанном для того, чтобы такие компании платили большую долю налогов в тех странах, где они получают прибыль, а не в тех, где они формально зарегистрированы. Поскольку правительства стран ЕС намерены принять чрезвычайные экспансионистские фискальные меры для стимулирования экономики, оказавшейся в «искусственной коме» из-за масштабных национальных запретов, привлекательность цифрового налога значительно возросла [Laffitte et al., 2020]. Об этом свидетельствует то, что цифровой налог был включен в число источников финансирования плана восстановления после пандемии «Следующее поколение ЕС», недавно обнародованного Европейской комиссией, хотя подробности того, как он будет функционировать, еще неизвестны.

Показав, насколько важны цифровые услуги для экономики европейских стран, коронавирус также заставил правительства ЕС остро осознать свою зависимость от иностранных компаний, особенно транснациональных корпораций США, при предоставлении этих услуг. Доминирование американских цифровых гигантов на рынке придает новое значение обсуждению амбиций ЕС в отношении «технологического суверенитета». Хотя план «Следующее поколение ЕС», кажется, предусматривает амбициозный режим цифровых инвестиций для смягчения структурной отсталости ЕС в области цифровых технологий, ЕС должен и далее укреплять свою роль мирового лидера в области технологического регулирования. Цифровое регулирование может усилить международное влияние ЕС, поскольку оно становится все более актуальным с точки зрения геополитического баланса. Однако именно по этой причине оно может вызвать серьезную напряженность в отношениях с США.

\section{Крупные технологические компании США: победители в условиях кризиса COVID-19}

Пандемия COVID-19 сильно повлияла на транснациональные интернет-корпорации, нарушив их бизнес-модели и нанеся ущерб их наиболее прибыльным видам деятельности. Airbnb, онлайн-платформа для сдачи в аренду недвижимости и свободных комнат, серьезно пострадала из-за ограничений на поездки и последующего упадка индустрии туризма. Сообщается, что компания потеряла около $90 \%$ бронирований, а ее рыночная стоимость за два месяца понизилась с 31 млрд до 26 млрд долл. США, то есть на $16 \%$ [Lee, 2020]. Uber, ведущая мировая платформа для поездок на такси, столкнулась с 80\%-м падением глобального спроса на поездки по сравнению с прошлым годом [Efrati, 2020]. По оценкам Cowne \& Co., Alphabet и Facebook потеряют в 2020 г. соответственно около 28,6 млрд и 15,7 млрд долл. США доходов от цифровой рекламы [Fischer, 2020]. Замедление экономики и падение спроса заставляют компании рационализировать свои стратегии расходов и маркетинга. Таким образом, неудивительно, что рыночная капитализация пяти крупнейших технологических гигантов (Alphabet, Amazon, Apple, Facebook и Microsoft) за период с февраля по март снизилась более чем на 1 трлн долл. США. 


\section{Однако это только одна сторона вопроса}

Спустя короткое время капитализация данных компаний снова начала расти, составив в апреле пятую часть от рыночной капитализации всех компаний индекса технологического сектора Nasdaq 100 [Wigglesworth, 2020]. Согласно их последним квартальным результатам, мировая изоляция стимулирует спрос на цифровые продукты и услуги, основными поставщиками которых они являются. Таким образом, крупные технологические компании могут выйти из кризиса с более сильными рыночными позициями.

Microsoft завершила квартал с выручкой в 35 млрд долл. США (рост на $15 \%$ в сравнении с прошлым годом), а чистая прибыль компании составила 10,8 млрд долл. США (+22\%). Доходы облачного сегмента Intelligent Cloud выросли на 27,28\%. Рост общей выручки компании Alphabet в 1-м квартале 2020 г. составил 13,2\%. Прибыль была обеспечена за счет рекламного сегмента Google $(+10,4 \%)$, рекламы на YouTube $(+33,49 \%)$ и Google Cloud $(+52,1 \%)^{2}$. Выручка компании Facebook в рассматриваемый период увеличилась на $15 \%$, а чистая прибыль - на 50,4\%3.

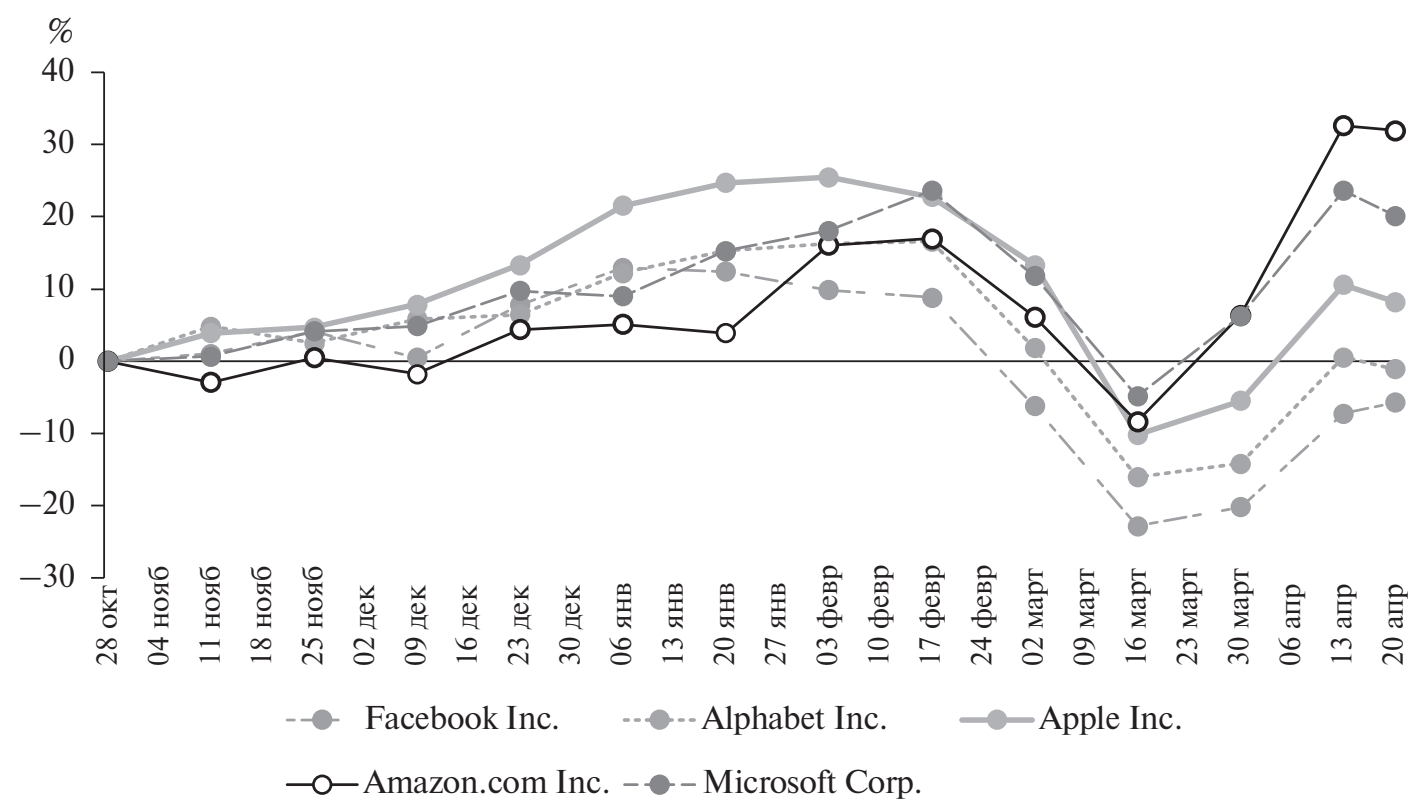

Рuc. 1. Изменение рыночной капитализации крупных технологических компаний с октября 2019 г. по апрель 2020 г., \%

Источник: Составлено авторами на основе: Financial Times, Markets Data <https://markets. ft.com/data>.

Несмотря на негативные последствия принудительного закрытия магазинов и временного нарушения цепочек создания стоимости, Apple после кризиса может показать рост. Компания из Купертино пытается диверсифицировать свою бизнес-модель, находя новые источники дохода, такие как Apple Music или Apple TV. Результаты 2-го квартала демонстрируют небольшое снижение чистых продаж продуктов iPhone, Мас и

${ }^{2}$ Alphabet, Alphabet Announces First Quarter 2020 Results. 28 April $2020<$ https://abc.xyz/investor/ static/pdf/2020Q1_alphabet_earnings_release.pdf>.

${ }^{3}$ Facebook, Facebook Reports First Quarter 2020 Results. 29 April $2020<$ https://prn.to/2KRljSb $>$. 
iPad (-6,65\% в сравнении с аналогичным периодом прошлого года), при этом отмечен резкий рост в сегменте услуг $(+16,5 \%)$ и в сегменте носимых устройств, устройств для дома и аксессуаров (+22,5\%) [Apple Inc., 2020]. В целом Apple завершила 2-й квартал с валовой прибылью, превышающей показатель того же квартала предыдущего года $(+2,45 \%)$, и меньшей чистой прибылью в размере 11,249 млрд долл. США $(-2,7 \%)$ из-за увеличения расходов на НИОКР $(+13,5 \%)^{4}$.

Компания Amazon сообщила о неоднозначных результатах, зафиксировав огромный скачок выручки от продаж $(+26 \%)$ и одновременное замедление роста прибыли из-за увеличения операционных расходов (транспортные расходы выросли на $49 \%$ до 10,9 млрд долл. США). Однако стоит отметить, что Amazon Web Services показал очень хорошие результаты (+33\%), обеспечив 77\% общей операционной прибыли Amazon 5 .

Эти цифры показывают, что поведение ограниченных в перемещении потребителей в условиях, когда физические точки розничной торговли закрыты, меняется таким образом, что приносит больше выгод поставщикам цифровых услуг и продуктов. Даже если этот сдвиг в предпочтениях обусловлен временной изоляцией, он может повлиять на долгосрочные привычки потребителей. Если некоторые люди оценили удобство и комфорт доставки продуктов и товаров на дом, например, с помощью Amazon Grocery Home Delivery, они, вероятно, продолжат использовать этот сервис даже после нормализации ситуации. Кроме того, пандемия COVID-19 вынуждает многих сотрудников работать дома. Корпоративные клиенты увеличивают спрос на онлайн-платформы для общения и совместной работы и, что более важно, на дальнейшую цифровизацию своих сетей и базовой инфраструктуры.

Компании, у которых нет средств для развития собственной инфраструктуры Интернета, предпочитают полагаться на сторонние решения, предлагаемые поставщиками технологических услуг. Несмотря на то что глобальный экономический спад, вероятно, приведет к сокращению бюджета компаний, потенциально замедляя инвестиции в цифровую трансформацию, пандемия COVID-19 сделала цифровизацию цепочек создания стоимости приоритетным направлением для поддержания и повышения производительности. Устойчивый рост доходов, генерируемый сегментом облачных вычислений (если посмотреть на лидеров рынка: Amazon Web Services, Microsoft Azure и Google Cloud), явно указывает на эту тенденцию (рис. 2).

Помимо того, что в целом крупные технологические компании показали хорошие результаты во время пандемии, они, похоже, лучше других подготовлены к глобальным экономическим проблемам в постпандемическом мире. В период одновременного глобального шока спроса и предложения, такого как нынешний, уровень денежных резервов частных компаний имеет решающее значение для того, чтобы выдержать кризис и развиваться после него. Когда фондовый рынок обрушивается, наличные деньги играют ключевую роль, обеспечивая необходимую ликвидность для финансирования операций, расходов на поглощения, на исследования и разработки. Суммарные денежные резервы компаний Amazon, Alphabet, Apple и Facebook составляют более 452 млрд долл. США [Stevens, 2019]. Даже с учетом их корпоративного долга балансы крупных технологических компаний выглядят крайне устойчиво, гарантируя наличие огромных средств для инвестирования в новые направления бизнеса, субсидирования убыточной деятельности, покупки других компаний с целью расширения своей экосистемы и в конечном счете укрепления своего рыночного влияния.

\footnotetext{
${ }^{4}$ Apple Inc., Apple Reports Second Quarter Results. 30 April $2020<$ https://www.apple.com/newsroom/2020/04/apple-reports-second-quarter-results>.

${ }^{5}$ Amazon, Amazon.com Announces First Quarter Results. 30 April $2020<$ https://ir.aboutamazon.com/ news-release/news-release-details/2020/Amazoncom-Announces-First-Quarter/default.aspx $>$.
} 


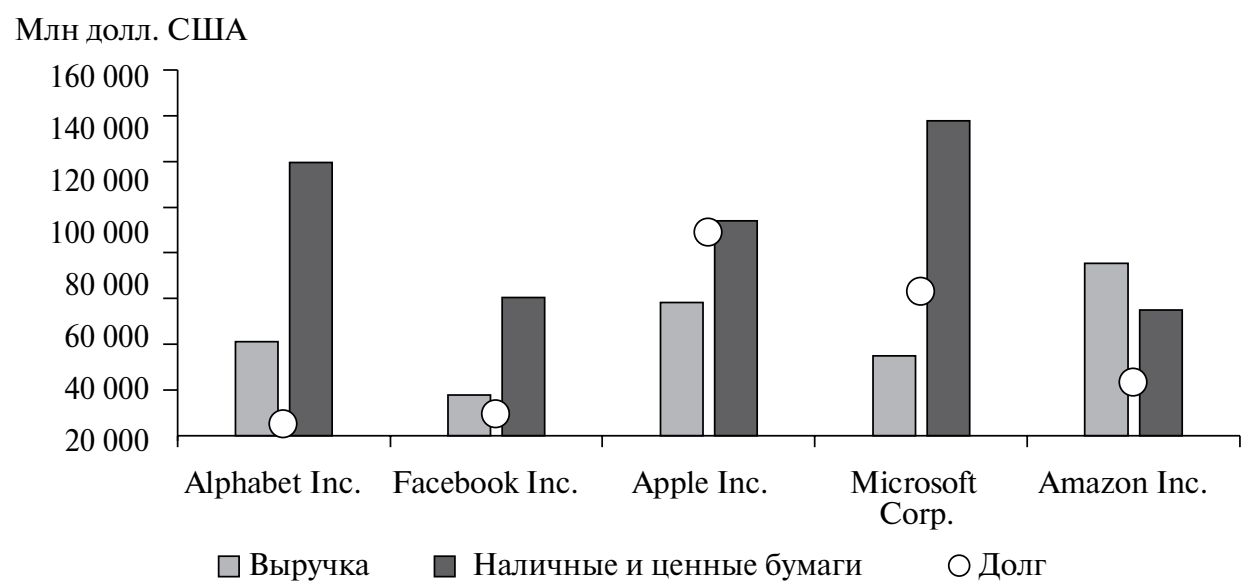

Pис. 2. Показатели выручки, наличных денежных средств, рыночных ценных бумаг и долга крупных технологических компаний в 1-м квартале 2020 г., млн долл. США

Источник: Составлено автором на основе результатов 1-го квартала компаний Alphabet, Facebook, Apple, Microsoft и Amazon.

\section{Европа - первопроходец введения цифрового налога}

Существующая международная налогово-бюджетная система часто критикуется за несоответствие современным требованиям, поскольку она по-прежнему основана на двух главных критериях распределения налоговых полномочий: «резидентстве» (страна, в которой расположена штаб-квартира компании и где она в обычных условиях платит корпоративный налог) и «источнике» (страна, в которой компания фактически продает свои товары или услуги и где она платит налог на добавленную стоимость (НДС)). Различие двух критериев очевидно применительно к традиционным цепочкам создания стоимости, основанным на материальных активах. Но применение такого подхода становится затруднительным, когда стоимость создается за счет нематериальных активов, способствуя размыванию налоговой базы и перемещению прибыли (рис. 3).

Глобальные цифровые транснациональные корпорации платят корпоративный налог по средней ставке около 9,5\%, тогда как для традиционных фирм средний показатель составляет 23,2\% [European Commission, 2018b]. В ЕС практики перемещения прибыли особенно агрессивны, поскольку компании могут использовать пробелы и несоответствия в международных налоговых правилах для перемещения прибыли в юрисдикции с низкими налогами в рамках единого европейского рынка. Европейская комиссия начала тщательное расследование этих практик. Самый яркий пример - это 13 млрд евро в виде неуплаченных Ирландии налогов, запрошенных у Apple. Европейская комиссия утверждала, что эффективная ставка корпоративного налога, применяемая к европейской прибыли дочерней компании Apple, зарегистрированной в Ирландии, составляла всего 1\% в 2003 г., снизившись до 0,005\% в 2014 г. ${ }^{6}$ Комиссия обвинила

${ }^{6}$ European Commission, State Aid: Ireland Gave Illegal Tax Benefits to Apple Worth Up to €13 Billion. 30 August $2016<$ https://ec.europa.eu/commission/presscorner/detail/en/IP_16_2923>. 
Люксембург в предоставлении Amazon аналогичных налоговых льгот 7 . Эти два запроса вызвали более широкую дискуссию о том, как цифровые преобразования сделали существующую налоговую систему устаревшей.

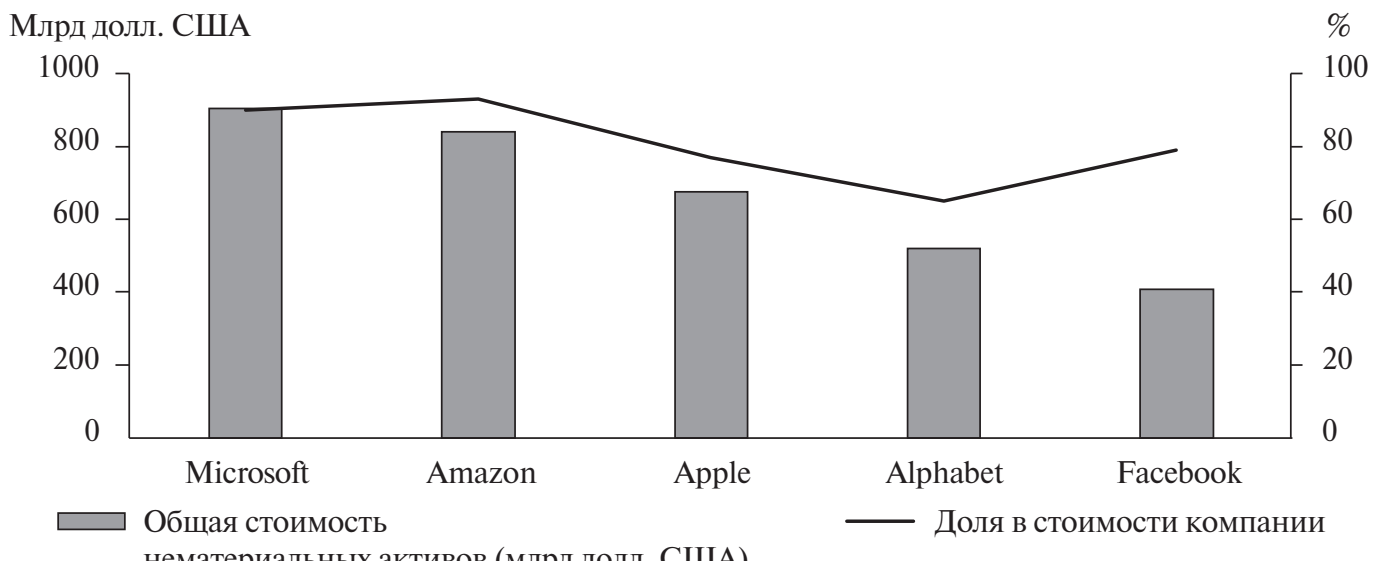

Puc. 3. Пятерка крупнейших компаний по общему объему нематериальных активов и их доле в стоимости компании в 2019 г., млрд долл. США

Источник: Составлено автором на основе: Brand Finance, Global Intangible Finance Tracker (GIFT ${ }^{\mathrm{TM}}$ ) 2019. November $2019<$ https://brandirectory.com/reports/global-intangible-finance-trackergift-2019>.

В 2018 г. Европейская комиссия представила два предложения по реформированию налоговой системы с целью устранить существующие в ней лазейки [European Commission, 2018a]. Первое предложение предполагало изменение концепции «резидентства», а второе, более легкое в реализации, предусматривало введение временного $3 \%$-го налога на доходы, полученные от продажи цифровых услуг и создания стоимости за счет пользователей. Налог должен был применяться к глобальным транснациональным корпорациям с общим доходом более 750 млн евро и доходом, полученным на европейском едином рынке, превышающим 50 млн евро.

Однако к марту 2019 г. Европейская комиссия зашла в тупик и не смогла прийти к соглашению со странами-членами. Правительства некоторых стран (во главе с Нидерландами, Ирландией и Люксембургом) выступили против обеих инициатив. Эти страны пользуются существующей налоговой асимметрией в рамках единого рынка, привлекая крупные транснациональные корпорации более низкими ставками корпоративного налога в своего рода «гонке уступок». В Ирландии, например, от 20 до 60\% государственных доходов от корпоративных налогов (3-6 млрд из 10,4 млрд евро) связаны с «превышением», что означает, что они «[доходы] превышают уровень, который можно было бы спрогнозировать на основе базовых показателей экономики и исходя из исторических / международных норм» [Irish Fiscal Advisory Council, 2019]. По данным независимой международной сети Tax Justice, в 2017 г. более 44 млрд долл. США прибыли крупных транснациональных корпораций были задекларированы в Нидерландах, а не в странах ЕС, в которых они были получены, что привело к значитель-

${ }^{7}$ European Commission, State Aid: Commission Finds Luxembourg Gave Illegal Tax Benefits to Amazon Worth Around €250 Million. 4 October $2017<$ https://ec.europa.eu/commission/presscorner/detail/en/ IP_17_3701>. 
ным налоговым потерям на национальном уровне: 2,7 млрд долл. США во Франции, по 1,5 млрд долл. США в Италии и Германии и 1 млрд долл. США в Испании ${ }^{8}$ В отчете указано, что из-за налоговых льгот, предоставленных Нидерландами, на каждый доллар, полученный Амстердамом в виде налога с перемещенной прибыли американских корпораций, пришлись потери корпоративного налога других стран ЕС в сумме почти 4 долл.

Другие государства-члены, например, Скандинавские страны, относятся к цифровому налогу с осторожностью, поскольку считают, что он может замедлить инновации и нанести ущерб их собственным цифровым транснациональным корпорациям (в странах Северной Европы расположено несколько крупных цифровых транснациональных корпораций, таких как компания Spotify). Поэтому они отказались поддержать общеевропейскую инициативу, выступив за многосторонний подход [Guarascio, 2018].

Из-за политического тупика в Европе некоторые государства-члены прибегли к введению национального цифрового налога. Однако это вызвало серьезную напряженность в отношениях с администрацией Дональда Трампа. США обеспокоены тем, что после введения цифрового налога на национальном (или европейском) уровне транснациональные корпорации США потенциально могут произвести вычет увеличения налогов, которые они платят странам ЕС, из своих налоговых обязательств в США. Основной источник этого беспокойства - французское правительство. В июле 2019 г. оно утвердило 3\%-й налог на доходы крупнейших цифровых транснациональных корпораций, работающих на национальном рынке (с глобальной выручкой более 750 млн евро, из которых не менее 25 млн было сгенерировано во Франции) [France, 2019]. По словам министра экономики Франции Брюно Ле Мэра, налог применим примерно к 30 крупным транснациональным корпорациям (в основном американским, но также китайским, немецким и французским) и мог бы приносить около 500 млн евро в год [De Clercq, Pineau, 2019]. В ответ президент США Трамп поручил своему торговому представителю начать расследование французского цифрового налога, в результате которого был сделан вывод о том, что налог «дискриминирует компании США» с «целью наказания определенных американских технологических компаний» [US Trade Representative, 2019a]. В отчете предлагалось принять ответные меры, установив тарифы в 100\% на 2,4 млрд долл. США французского импорта, включая такие товары, как вино и сыр, и провести дальнейшее исследование аналогичных инициатив, предложенных Италией, Турцией и Австрией [Ibid., 2019b].

После нескольких месяцев конфликта в январе 2020 г. Трамп и его французский коллега Эммануэль Макрон объявили о компромиссе. США согласились приостановить предложенные тарифы до конца 2020 г., а правительство Франции отложило уплату цифрового налога до декабря 2020 г., когда Организация экономического сотрудничества и развития (ОЭСР) должна опубликовать свое предложение по реформированию налоговой системы.

Предложение ОЭСР иногда преподносится как чудодейственное средство, способное согласовать различные интересы правительств, а также частного сектора. Крупнейшие цифровые транснациональные корпорации поддержали многосторонние усилия ОЭСР, признав, что глобальная экономика с национальными цифровыми налогами может многократно увеличить их затраты на соблюдение нормативных

${ }^{8}$ Tax Justice Network, Revealed: Netherlands, Blocking EU's Covid19 Recovery Plan, Has Cost EU Countries \$10bn in Lost Corporate Tax a Year. 8 April $2020<$ https://www.taxjustice.net/2020/04/08/revealednetherlands-blocking-eus-covid19-recovery-plan-has-cost-eu-countries-10bn-in-lostcorporate-tax-a-year $>$. 
требований, нанеся ущерб бизнесу. С точки зрения экономической эффективности пересмотренная глобальная система действительно гарантирует налоговую определенность, снижая риски негативного воздействия на инвестиции в инновации.

В январе 2020 г. ОЭСР выпустила заявление, в котором описала обсуждаемый подход как включающий: (а) определение типа компаний, на которые распространяется новое законодательство; (б) определение части их прибыли, которая подлежит налогообложению; и, наконец, (в) указание минимального уровня налогов, которые должны платить международные компании. Таким образом, заявление ОЭСР имело решающее значение для определения общей архитектуры глобальной налоговой системы.

Во-первых, в рамках ОЭСР определяется, какие компании будут облагаться налогом. В одну группу входят компании, которые получают доход с помощью автоматизированных цифровых сервисов, такие как поисковые системы (например, Google), социальные сети (Facebook) и онлайн-платформы посредничества (Amazon). Другая группа включает ориентированные на потребителя компании, которые увеличивают стоимость продукта (и, следовательно, прибыль самой компании), например, с помощью целевых маркетинговых стратегий или стратегий узнаваемости бренда, реализуемых без необходимости физического присутствия в юрисдикции потребителя (напримep, Apple).

Во-вторых, в документе ОЭСР утверждается, что оценка прибыли больше не должна основываться на подходе «отдельных структур», который определяет дочернюю компанию как автономную структуру, а должна базироваться на концепции финансовой группы как единой структуры. Если эта консолидированная группа получает прибыль выше определенного уровня (который еще предстоит определить) и если прибыль генерируется любым из четырех видов деятельности, описанных выше, группа должна уплатить процент налогов с прибыли, превышающей установленное пороговое значение.

В-третьих, предложение ОЭСР касается вопроса обеспечения минимального уровня налогообложения для каждой транснациональной группы в рыночных юрисдикциях, где осуществляется базовая маркетинговая деятельность и дистрибуция. Главная цель - уменьшить стимулы для крупных транснациональных корпораций переводить свою прибыль в юрисдикции с низкими или нулевыми налоговыми ставками. Концепция, лежащая в основе этого (еще не сформированного) предложения, заключается в том, что если страна применяет налоговый режим, который позволяет многонациональной компании платить налог на весь свой оборот по ставке ниже минимального уровня (еще подлежит определению), другие государства могут увеличить налоговое бремя, уменьшив вычеты из налоговой базы и льготы, на которые имеют право транснациональные корпорациия.

Достижение консенсуса в отношении теоретических основ глобальной налоговой системы - это фундаментальный шаг. Тем не менее государства все еще обсуждают многочисленные детали работы. Среди них основная проблема заключается в определении минимального уровня прибыли, ниже которого новый режим не будет применяться, - узел, который трудно развязать также из-за его политических последствий. Некоторые государства также хотят использовать формулу для расчета прибыли, свя-

${ }^{9}$ Представьте себе расчет, основанный на соотношении между глобальным оборотом транснациональной компании (в знаменателе) и общими налогами, уплаченными во всем мире в различных юрисдикциях, в которых работает компания (в числителе). Если это соотношение оказывается меньше согласованного глобального минимального налога, страны с высокими налоговыми ставками могут потребовать еще более высокого налогообложения прибыли транснациональной компании, сократив вычеты и льготы. 
занной с деятельностью бизнеса, независимо от физического присутствия, в рыночной юрисдикции, чтобы учесть различные степени цифровизации транснациональных корпораций. По общему мнению, требуется эффективный механизм предотвращения и разрешения споров, а также новый метод избежания двойного налогообложения, но подробности по обоим вопросам отсутствуют. Еще более сложной проблемой является неоднозначная позиция США. Вашингтон хотел бы сделать новый режим факультативным, основанным на добровольном присоединении транснациональных корпораций (на основе принципа безопасной гавани). Однако это подорвет эффективность реформы. Американское предложение встретило сопротивление со стороны основных стран ЕС, которые объявили этот вариант нежизнеспособным [Guarascio, 2020].

Многостороннее решение ОЭСР могло бы также получить импульс вследствие растущего давления групп интересов и общественного мнения, а также нежелания таких стран, как Дания и Польша, предоставлять налоговые льготы транснациональным компаниям, зарегистрированным в налоговых убежищах.

\section{COVID-19 и европейские амбиции «технологического суверенитета»}

Расхождения между США и ЕС выходят за рамки цифровых налогов. В Европе дебаты о введении цифрового налога на национальном или глобальном уровне были частью более широкой дискуссии о ее зависимости от цифровых услуг, предоставляемых иностранными компаниями.

Если COVID-19 в итоге укрепит доминирующее положение на рынке крупных технологических компаний, это усилит функцию цифрового посредничества транснациональных корпораций США в экономиках ЕС. Изоляция показала, что крупные технологические компании США играют ключевую роль «привратника» в европейской цифровой архитектуре, являясь посредником во взаимодействии между потребителями из ЕС и цифровыми услугами. Цифровые транснациональные корпорации США использовали неразвитость внутреннего цифрового сектора ЕС и добились доминирования на европейских рынках ${ }^{10}$. Во время изоляции в связи с COVID-19 крупные технологические компании США взяли на себя функцию общественного пользования, де-факто поддерживая национальные правительства и частные компании в их реагировании на кризис. Премьер-министр Италии Джузеппе Конте часто транслировал свои официальные заявления на Facebook; Google и Apple внесли изменения в свои операционные системы, чтобы обеспечить отслеживание контактов пациентов с COVID-19 на основе Bluetooth, предложив это решение правительствам [Scott et al., 2020]; Bceмирная организация здравоохранения использовала принадлежащеe Facebook приложение WhatsApp для распространения информации о вирусе; Amazon поддержала домохозяйства во время изоляции, доставляя товары на дом. Это лишь несколько примеров жизненно важных функций, которые цифровые гиганты США выполняли в Европе (и за ее пределами).

Эта мегатенденция, вероятно, находится только в начале своего развития. Случай с производством автомобилей, которое было одним из промышленных столпов мировой экономики после Второй мировой войны, показателен. Крупные технологические компании возглавляют исследования и разработки в области беспилотных автомобилей, вступая в партнерства с признанными лидерами автопроизводства (например,

${ }^{10}$ Например, Android и iOS - операционные системы Alphabet и Apple - установлены на 99,49\% смартфонов, работающих в Европе. Поисковая система Google занимает около 93,51\% рынка ЕС. 
проект е-Palette между Toyota и Amazon), инвестируя в стартапы (например, инвестиции Amazon в Aurora, ведущий стартап в области технологий беспилотных автомобилей) или путем разработки собственных технологий (например, Apple, Alphabet или Baidu). Столь же стремительно развиваются события в банковском секторе, где крупные технологические компании укрепляют свои рыночные позиции, запуская собственные услуги и продукты (такие как Google Pay, Apple Рау и т.д.) или вступая в партнерские отношения с действующими банками (например, Microsoft и Nexi, Apple и Goldman Sachs). Этот сценарий воплощает то, что Янсити и Лахани называют экономикой хабов: конкуренция между крупнейшими цифровыми транснациональными корпорациями, которые приобретают сетевые активы, «уже достигшие масштаба в одной среде, а затем используют их для выхода в другую отрасль и “реорганизации” ее конкурентной структуры» [Iansiti, Lakhani, 2017]. Поступая таким образом, американские фирмы настроены на дальнейшую консолидацию и укрепление уже сформированных доминирующих позиций на цифровых рынках EC [Leonard et al., 2019].

В связи с эти возникает вопрос: может ли это доминирование нанести вред долгосрочному экономическому развитию ЕС и подорвать его глобальные амбиции? В частном документе Европейской комиссии, просочившемся в сеть в 2019 г., отмечается, что полагаться на оборудование и программное обеспечение третьих стран «означает полагаться на их ценности». Опора на других может в конечном счете подорвать «позиции и влияние Европы на мировых рынках $<\ldots>$, поставив под угрозу наш технологический суверенитет в ключевых промышленных стратегических цепочках создания стоимости» [Gallagher, Drozdiak, 2019]. В результате этого растущего осознания технологической зависимости ЕС председатель Европейской комиссии Урсула фон дер Ляйен повторила в своем политическом манифесте, что ЕС должен стремиться к «технологическому суверенитету», продвигая инвестиции в такие ключевые области, как квантовые вычисления, алгоритмы и инструменты для обмена данными.

Согласно упомянутому документу, официальные лица ЕС призывали к созданию Европейского фонда будущего, который мог бы инвестировать более 100 млрд евро в пакеты акций компаний ЕС с высоким потенциалом. Предложение было направлено на снижение чрезмерной зависимости Европы от цифровых услуг, предоставляемых иностранными компаниями, с признанием того факта, что сфера технологий стала (и будет впредь) полем битвы за экономический рост. Поскольку компании ЕС в настоящее время не могут конкурировать ни с масштабом фондового рынка США, ни со стоимостью технологической отрасли Китая, контролируемой государством, официальные лица ЕС разработали гибридный план, который мог бы стимулировать государственное вмешательство на частном рынке ЕС (рис. 4).

Два фактора могут существенно подорвать технологические амбиции ЕС. Вопервых, с Brexit ЕС теряет один из своих инновационных центров. По данным СВ Insights, в Великобритании зарегистрированы технологические компании-единороги общей стоимостью почти 50 млрд долл. США (например, финтех-компании Revolut, Monzo, Transferwise и Stripe или многопользовательский центр обработки данных Global Switch). Во-вторых, пандемия COVID-19 оказала существенное влияние на экономику стран ЕC, что потребовало принятия чрезвычайных мер бюджетной экспансии для поддержки доходов домохозяйств и компаний как на национальном, так и на европейском уровне. Если ЕС не сформулирует свой план восстановления с упором на развитие цифровой экономики, на национальном уровне государства ЕС вряд ли найдут необходимые ресурсы для реализации амбициозного плана цифровой трансформации. Этот акцент поддерживается новым инструментом восстановления «Следующее поколение ЕС», который признает, что цифровизация лежит в основе будущего ЕС. 
В предложении подчеркивается стремление инвестировать в цифровую инфраструктуру, технические разработки (например, в области искусственного интеллекта и облачных вычислений) и связанные с данными активы. О реализации плана пока слишком мало информации, но он представляется уникальной возможностью для ЕС сократить технологическое отставание от США и Китая, тем самым уменьшив зависимость от иностранных цифровых услуг (рис. 5).

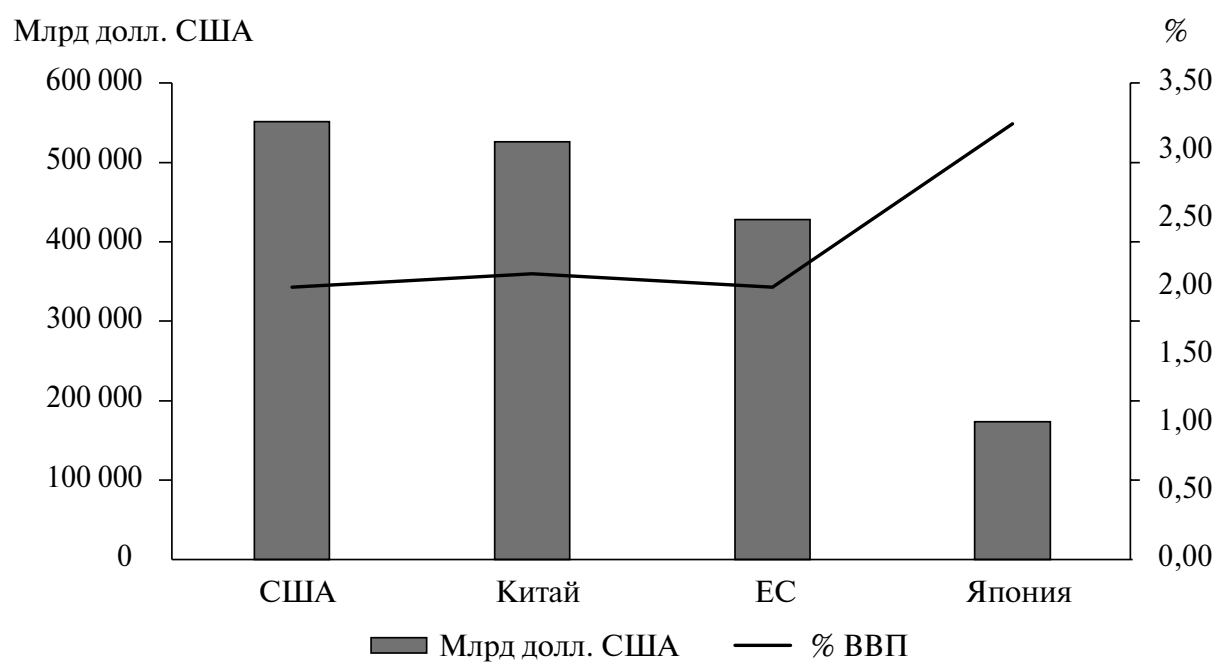

Puc. 4. Валовые внутренние расходы на НИОКР и их доля в ВВП в 2018 г., млрд долл. США

Источник: Составлено автором на основе данных ОЭСР: Gross Domestic Spending on R\&D $<$ https://data.oecd.org/rd/gross-domestic-spending-on-r-d.htm>.

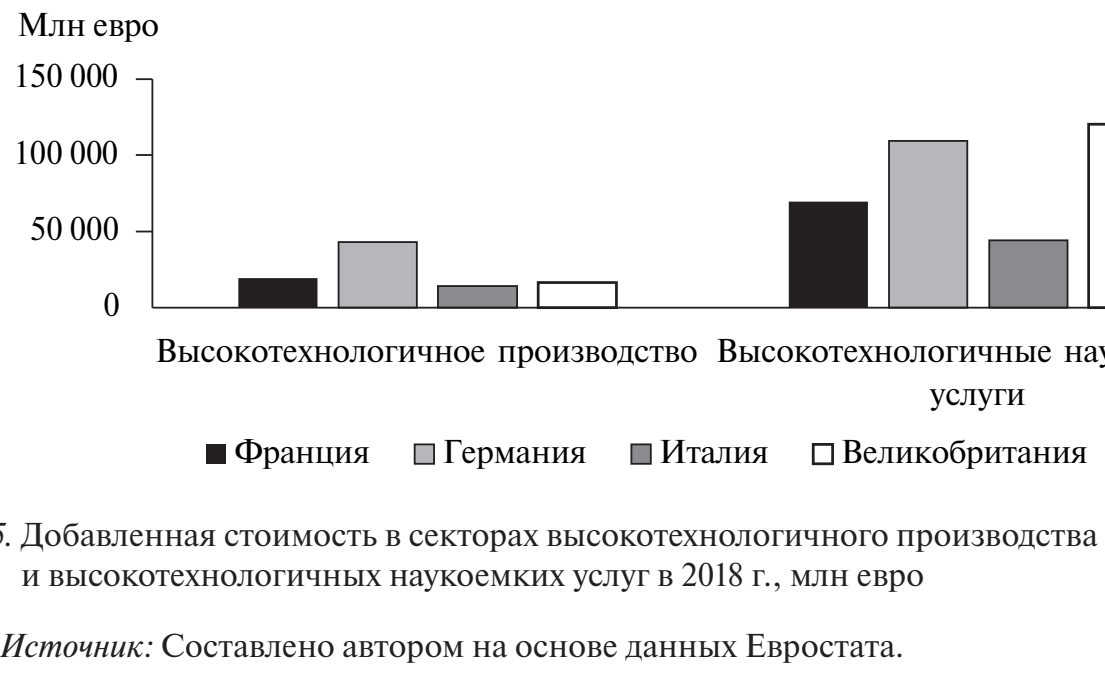

Несмотря на эти критические факторы, ЕС, вероятно, продолжит укреплять свою роль мирового лидера в области регулирования технологий. Учитывая, что ни одна цифровая компания не желает отказываться от крупного и богатого потребительского рынка ЕС, последний смог сформировать глобальный дискурс о регулировании технологий. Как первопроходец в области такого регулирования ЕС повлиял на другие 
юрисдикции и установил глобальные стандарты, о чем свидетельствует влияние Общего регламента по защите данных (GDPR), который привел к пересмотру законов о конфиденциальности в 120 странах.

Ожидается, что в 2020 г. роль ЕС как динамичного глобального регулирующего актора увеличится в связи с подготовкой нового Закона о цифровых услугах, который, вероятно, введет более строгие правила для управления интернет-платформами и регулирования разработок в области искусственного интеллекта [Kahn, Murgia, 2019]. Кроме того, с утверждением Маргрет Вестагер в качестве комиссара ЕС по конкуренции Комиссия провела антимонопольные расследования доминирующего положения в ЕС американских цифровых транснациональных корпораций, включая Alphabet и Qualcomm, оштрафованных на 3,8 млрд и 242 млн евро соответственно. В период с января по июнь 2019 г. 49\% глобальных предложений по регулированию технологической отрасли исходили от ЕС или его стран-членов, и более половины этих предложений касались конкуренции и структуры компаний [Schöning et al., 2019].

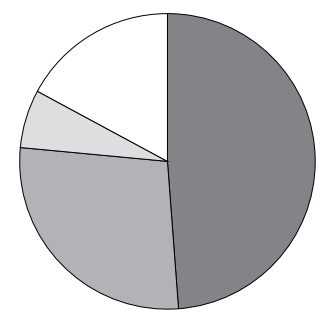

$\square$ ЕС $\square$ США $\square$ Россия $\square$ Другие

Puc. 6. Количество предложений по регулированию технологических отраслей, июнь - январь 2019 г.

Источник: Составлено автором на основе: Murgia M. Europe 'A Global Trendsetter on Tech Regulation’ // Financial Times. 2019. 30 October <https://on.ft.com/32Y821P $>$.

Скорее всего, стремление ЕС стать мировым лидером в области регулирования технологий еще более усилит напряженность в отношениях с США. Президент Трамп резко раскритиковал деятельность ЕС в области регулирования, в том числе антимонопольные расследования Европейской комиссии. В интервью Трамп заявил, что ЕС искал «легких денег», расследуя поведение американских цифровых компаний на рынке [Kelly, 2019]. В позиции Трампа нет ничего нового. Бывший президент США Барак Обама также неоднократно критиковал политику ЕС в отношении цифровых транснациональных корпораций США, называя эти действия технологическим протекционизмом против американских фирм, движимым коммерческими интересами [Ahmed et al., 2019]. Усиление технологического регулирования, введенного ЕС, может привести к формированию регуляторного лага между ЕС и США, потенциально повышая барьеры для трансатлантической торговли и инвестиций и в конечном счете подрывая потенциал трансатлантических экономических отношений.

\section{Заключение}

Крупные технологические компании выходят победителями из кризиса COVID-19. Глобальная изоляция привела к росту цифровизации экономики, увеличив спрос на 
государственные, корпоративные и розничные цифровые услуги. Эта мегатенденция укрепила доминирующее положение цифровых транснациональных корпораций США на рынках ЕС, поставив под сомнение способность последнего реализовать свои амбиции по обеспечению технологического суверенитета. Но еще хуже другое. Поскольку государственные расходы находятся под огромным давлением политики активной бюджетной экспансии стран-членов и институтов ЕС, направленной на оживление экономики, возможности для инвестиций в технологии могут сократиться.

В этом контексте некоторые европейские политики предлагают ускорить введение цифрового налога, чтобы расширить налоговую базу и предоставить нуждающимся в денежных средствах правительствам столь необходимый им источник новых доходов. Этот вопрос традиционно вызывает разногласия в ЕС и напряженность в отношениях с США. Чтобы смягчить оба конфликта, ЕС пошел на компромисс, согласившись отложить односторонние инициативы и поддержать многосторонние переговоры, проводимые в рамках ОЭСР, которая намеревается провести пересмотр глобальной цифровой налоговой системы к декабрю 2020 г. Однако нет уверенности в том, что компромисс возможен, не в последнюю очередь потому, что США относятся к усилиям ЕС в области цифрового налогообложения с большим скептицизмом, если не с открытой враждебностью: инициативы ЕС в области регулирования в основном направлены на цифровые транснациональные корпорации США.

Для ЕС ставки высоки. Устанавливая технические стандарты и правила в области технологий, он может формировать и влиять на нормативно-правовую базу регулирования на международном уровне и обеспечивать основу для процветания рынков на основе функциональной совместимости между технологиями и снижения торговых издержек на своем внутреннем рынке. Техническое регулирование также укрепит геополитическую мощь ЕС благодаря возможным вторичным эффектам в нормативноправовой базе других стран, тем самым формируя стандарты и предпочтения на региональном и даже глобальном уровне.

Однако этого подхода будет недостаточно для реализации геополитических амбиций ЕС - «технологического суверенитета». Мировое лидерство в сфере регулирования технологий должно сопровождаться ростом инвестиций для сокращения цифрового разрыва между ЕС и США с Китаем. Страны ЕС должны использовать весь свой политический вес в поддержку планов цифровых инвестиций, предусмотренных в программе Еврокомиссии «Следующее поколение ЕС». Если ЕС хочет иметь возможность конкурировать со стратегическими технологиями США или Китая, он должен начать наверстывать упущенное как можно раньше, потому что иначе может быть уже слишком поздно.

\section{Источники}

Ahmed M., Robinson D., Waters R. (2015) Obama Attacks Europe Over Technology Protectionism // Financial Times. Режим доступа: https:// www.ft.com/content/41d968d6-b5d2-11e4-b58d-00144feab7de (дата обращения: 11.11.2020).

Apple Inc. (2020) Condensed Consolidated Statements of Operations (Unaudited). Режим доступа: https:// www.apple.com/newsroom/pdfs/Q1\%20FY20\%20Consolidated\%20Financial\%20Statements.pdf (дата обращения: 11.11.2020).

Bradford A. (2020) How Europe Rules the Digital Economy // Project Syndicate Режим доступа: https:// prosyn.org/nIF1YUq (дата обращения: 11.11.2020). 
Chin B., Wamsley D. (2020) Tech Firms Are Swooping in to Profit From COVID-19 // Jacobin. Режим доступа: https://www.jacobinmag.com/2020/03/coronavirus-covid-tech-firms-telehealth (дата обращения: 11.11.2020).

Christensen R. (2020) The Impact of Covid-19 on Global Digital Tax Negotiations // ICTD Blog. Режим доступа: https://www.ictd.ac/blog/impactcoronavirus-global-digital-tax-negotiations-oecd (дата обращения: 11.11.2020).

Clercq G., Pineau E. (2019) French Tax on Internet Giants Could Yield 500 Million Euros Per Year: Le Maire // Reuters. Режим доступа: https://reut.rs/2NDQn8A (дата обращения: 11.11.2020).

Dwoskin E. (2020) Tech Giants Are Profiting - and Getting More Powerful - Even As the Global Economy Tanks // The Washington Post. Режим доступа: https://wapo.st/35gVioY (дата обращения: 11.11.2020).

Efrati A. (2020) Uber's Bookings Now Down 80\% // The Information. Режим доступа: https://www.theinformation.com/briefings/7120d9 (дата обращения: 11.11.2020).

European Commission. (2018a) Proposal for a Council Directive on the Common System of a Digital Services Tax on Revenues Resulting from the Provision of Certain Digital Services (COM/2018/148). Режим доступа: https://eur-lex.europa.eu/legal-content/EN/TXT/?uri=CELEX:52018PC0148 (дата обращения: 11.11.2020).

European Commission. (2018b) Time to Establish a Modern, Fair and Efficient Taxation Standard for the Digital Economy (COM/2018/146). Режим доступа: https://eur-lex.europa.eu/legal-content/EN/ TXT/?uri=CELEX:52018DC0146 (дата обращения: 11.11.2020).

Fischer S. (2020) Tech Giants Set to Lose Billions in Ad Revenue in Virus Shutdown // Ахіоs. Режим доступа: https://www.axios.com/f0e74396-6444-4c44-8aa7- 974dd3e89883.html (дата обращения: 11.11.2020).

Gallagher R., Drozdiak N. (2019) Europe Overly Dependent on Outside Technology, EU Memo Warns // Bloomberg. Режим доступа: https://www.bloomberg.com/news/articles/2019-09-30/eu-officials-call-fortechnologypush-to-counter-u-s-china (дата обращения: 11.11.2020).

Guarascio F. (2020) EU Tax Commissioner Slams U.S. Plans on Tech Tax // Reuters. Режим доступа: https://reut.rs/2SE8Fut (дата обращения: 11.11.2020).

Guarascio F. Nordic Countries Oppose EU Plans for Digital Tax on Firms' Turnover // Reuters. Режим доступа: https://reut.rs/2LdjxsV (дата обращения: 11.11.2020).

Iansiti M., Lakhani K. (2017) Managing Our Hub Economy: Strategy, Ethics, and Network Competition in the Age of Digital Superpowers // Harvard Business Review. Vol. 95. No. 5 (September-October 2017). P. 84-92.

Irish Fiscal Advisory Council. (2019) Fiscal Assessment Report, June. Режим доступа: https://www.fiscalcouncil.ie/?p=6201 (дата обращения: 11.11.2020).

Kahn M., Murgia M. (2019) EU Draws Up Sweeping Rules to Curb Illegal Online Content // Financial Times. Режим доступа: https://on.ft.com/2Yexug2 (дата обращения: 11.11.2020).

Kelly M. (2019) Donald Trump on Tech Antitrust: 'There's Something Going On // The Verge. Режим доступа: https://www.theverge.com/2019/6/10/18659619 (дата обращения: 11.11.2020).

Laffitte S. (2020) International Corporate Taxation after Covid-19: Minimum Taxation as the New Normal // CEPII Policy Briefs. No. 30. Режим доступа: http://www.cepii.fr/CEPII/en/publications/pb/abstract. asp?NoDoc=12596 (дата обращения: 11.11.2020).

Lee D. (2020) Airbnb Lowers Internal Valuation by $16 \%$ to \$26bn // Financial Times. Режим доступа: https:// on.ft.com/3bO840c (дата обращения: 11.11.2020).

Leonard M. Redefining Europe's Economic Sovereignty // Bruegel Policy Contributions. No. 9 (June 2019). Режим доступа: https://www.bruegel.org/?p=31321 (дата обращения: 11.11.2020).

Mangalindan J. (2020) How Will Alphabet Weather COVID-19 and Plunging Ad Sales? // Protocol. Режим доступа: https://www.protocol.com/coronavirus-alphabetgoogle-financial-outlook (дата обращения: 11.11.2020).

Microsoft. (2020) Earnings Release FY20 Q3. Режим доступа: //www.microsoft.com/en-us/Investor/earnings/FY-2020-Q3/press-release-webcast. 
Protalinski E. (2020) Amazon Reports \$75.5 Billion in Q1 2020 Revenue: AWS Up 33\%, Subscriptions Up $28 \%$, and 'Other' Up 44\% // Venture Beat. Режим доступа: https://wp.me/p8wLEc-aUgx (дата обращения: 11.11.2020).

Roose K., Dance G. (2020) The Coronavirus Revives Facebook as a News Powerhouse // The New York Times. Режим доступа: https://www.nytimes.com/2020/03/23/technology/coronavirus-facebook-news. html (дата обращения: 11.11.2020).

Schöning F. (2019) Michele Farquhar and Peter Watts, A Turning Point for Tech. Global Survey on Digital Revolution // Hogan Lovells. Режим доступа: https://www.hoganlovells.com/en/publications/a-turningpoint-for-tech-global-survey-on-digital-regulation (дата обращения: 11.11.2020).

Scott M. (2020) How Google and Apple Outflanked Governments in the Race to Build Coronavirus Apps // Politico. Режим доступа: https://www.politico.eu/article/google-apple-coronavirus-app-privacy-uk-francegermany (дата обращения: 11.11.2020).

Stevens P. Here Are the 10 Companies with the Most Cash on Hand // CNBC. Режим доступа: https://www. cnbc.com/2019/11/07/microsoft-apple-andalphabet-are-sitting-on-more-than-100-billion-in-cash.html (дата обращения: 11.11.2020).

Stolton S. (2020) Digital Brief, Powered by Facebook: Could Digital Tax Return to the EU? // Euractiv. Режим доступа: https://www.euractiv.com/section/digital/news/digital-brief-powered-by-facebook-coulddigital-tax-return-to-the-eu/1459700 (дата обращения: 11.11.2020).

US Trade Representative. (2019a) Conclusion of USTR's Investigation Under Section 301 into France's Digital Services Tax. Режим доступа: https://ustr.gov/node/10052.

US Trade Representative. (2019b) Report on France's Digital Services Tax. Режим доступа: https://ustr.gov/ sites/default/files/Report_On_France\%27s_Digital_Services_Tax.pdf

Waters R. (2020) Big Tech Has the Cash to Expand After Crisis // Financial Times. Режим доступа: https:// on.ft.com/3ddq7hL (дата обращения: 11.11.2020).

Wigglesworth R. (2020) How Big Tech Got Even Bigger in the Covid-19 Era // Financial Times. Режим доступа: https://on.ft.com/3aYaEQ9 (дата обращения: 11.11.2020).

Zara C. (2020) Amazon Stock Clobbered as Jeff Bezos Outlines COVID-19 Impact, Tells Investors to 'Take a Seat' // Fast Company. Режим доступа: https://www.fastcompany.com/90499642 https://on.ft.com/ 3aYaEQ9 (дата обращения: 11.11.2020). 


\title{
Beyond the Digital Tax: The Challenges of the EU's Scramble for Technological Sovereignty
}

\author{
N. Bilotta
}

Nicola Bilotta - Researcher at the Istituto Affari Internazionali (IAI); 9 Via Angelo Brunetti, Rome, Italy; E-mail: n.bilotta@iai.it

\begin{abstract}
The COVID-19 pandemic has laid bare how critical digital platforms are to the functioning of our economy. Big Tech companies are likely going to emerge stronger from the COVID-19 emergency, due to the massive surge in demand for public, retail and corporate digital services. This megatrend has consolidated the dominant market position of digital multinationals - almost all of them from the US - in the EU markets, raising critical questions ranging from the EU's ambition for technological sovereignty to the much more urgent issue of how Big Tech's profits should be taxed. The "digital tax" issue - already the source of a lively international debate before COVID-19- has gained in prominence as it would be an important instrument for governments in dire need of raising money to finance the post-pandemic economic recovery. With the digital tax included the Next Generation EU recovery fund presented by the European Commission, the EU is expected to further consolidate its global leadership in tech regulations. However, European regulatory activism could also raise barriers to transatlantic trade and investments, thus producing new tensions with the US.
\end{abstract}

Key words: Digital governance; Taxation; European Union; USA; Transatlantic relations; Coronavirus

For citation: Bilotta N. (2020) Beyond the Digital Tax: The Challenges of the EU's Scramble for Technological Sovereignty. International Organisations Research Journal, vol. 15, no 4, pp. 30-47 (in Russian). DOI: 10.17323/19967845-2020-04-02

\section{References}

Ahmed M., Robinson D., Waters R. (2015) Obama Attacks Europe Over Technology Protectionism. Financial Times. Available at: https:// www.ft.com/content/41d968d6-b5d2-11e4-b58d-00144feab7de (accessed 11 November 2020).

Apple Inc. (2020) Condensed Consolidated Statements of Operations (Unaudited). Available at: https://www. apple.com/newsroom/pdfs/Q1\%20FY20\%20Consolidated\%20Financial\%20Statements.pdf (accessed 11 November 2020).

Bradford A. (2020) How Europe Rules the Digital Economy. Project Syndicate. Режим доступа: https:// prosyn.org/nIF1YUq (accessed 11 November 2020).

Chin B., Wamsley D. (2020) Tech Firms Are Swooping in to Profit From COVID-19. Jacobin. Available at: https://www.jacobinmag.com/2020/03/coronavirus-covid-tech-firms-telehealth (accessed 11 November 2020).

Christensen R. (2020) The Impact of Covid-19 on Global Digital Tax Negotiations. ICTD Blog. Available at: https://www.ictd.ac/blog/impactcoronavirus-global-digital-tax-negotiations-oecd (accessed 11 November 2020).

Clercq G., Pineau E. (2019) French Tax on Internet Giants Could Yield 500 Million Euros Per Year: Le Maire. Reuters. Available at: https://reut.rs/2NDQn8A (accessed 11 November 2020).

Dwoskin E. (2020) Tech Giants Are Profiting - and Getting More Powerful - Even As the Global Economy Tanks. The Washington Post. Available at: https://wapo.st/35gVioY (accessed 11 November 2020).

Efrati A. (2020) Uber's Bookings Now Down 80\%. The Information. Available at: https://www.theinformation. com/briefings/7120d9 (accessed 11 November 2020). 
European Commission. (2018a) Proposal for a Council Directive on the Common System of a Digital Services Tax on Revenues Resulting from the Provision of Certain Digital Services (COM/2018/148). Available at: https://eur-lex.europa.eu/legal-content/EN/TXT/?uri=CELEX:52018PC0148 (accessed 11 November 2020).

European Commission. (2018b) Time to Establish a Modern, Fair and Efficient Taxation Standard for the Digital Economy (COM/2018/146). Available at: https://eur-lex.europa.eu/legal-content/EN/ TXT/?uri=CELEX:52018DC0146 (accessed 11 November 2020).

Fischer S. (2020) Tech Giants Set to Lose Billions in Ad Revenue in Virus Shutdown. Axios. Available at: https://www.axios.com/f0e74396-6444-4c44-8aa7- 974dd3e89883.html (accessed 11 November 2020).

Gallagher R., Drozdiak N. (2019) Europe Overly Dependent on Outside Technology, EU Memo Warns. Bloomberg. Available at: https://www.bloomberg.com/news/articles/2019-09-30/eu-officials-call-for-technologypush-to-counter-u-s-china (accessed 11 November 2020).

Guarascio F. Nordic Countries Oppose EU Plans for Digital Tax on Firms' Turnover. Reuters. Available at: https://reut.rs/2LdjxsV (accessed 11 November 2020).

Guarascio F. (2020) EU Tax Commissioner Slams U.S. Plans on Tech Tax. Reuters. Available at: https://reut. rs/2SE8Fut (accessed 11 November 2020).

Iansiti M., Lakhani K. (2017) Managing Our Hub Economy: Strategy, Ethics, and Network Competition in the Age of Digital Superpowers. Harvard Business Review, vol. 95, no 5 (September - October 2017), pp. 84-92.

Irish Fiscal Advisory Council. (2019) Fiscal Assessment Report, June. Available at: https://www.fiscalcouncil. ie/?p=6201 (accessed 11 November 2020).

Kahn M., Murgia M. (2019) EU Draws Up Sweeping Rules to Curb Illegal Online Content. Financial Times. Available at: https://on.ft.com/2Yexug2 (accessed 11 November 2020).

Kelly M. (2019) Donald Trump on Tech Antitrust: 'There's Something Going On. The Verge. Available at: https://www.theverge.com/2019/6/10/18659619 (accessed 11 November 2020).

Laffitte S. (2020) International Corporate Taxation after Covid-19: Minimum Taxation as the New Normal. CEPII Policy Briefs, no 30. Available at: http://www.cepii.fr/CEPII/en/publications/pb/abstract. asp? NoDoc $=12596($ accessed 11 November 2020).

Lee D. (2020) Airbnb Lowers Internal Valuation by $16 \%$ to $\$ 26 \mathrm{bn}$. Financial Times. Available at: https://on.ft. com/3bO840c (accessed 11 November 2020).

Leonard M. Redefining Europe's Economic Sovereignty. Bruegel Policy Contributions, no 9 (June 2019). Available at: https://www.bruegel.org/?p=31321 (accessed 11 November 2020).

Mangalindan J. (2020) How Will Alphabet Weather COVID-19 and Plunging Ad Sales? Protocol. Available at: https://www.protocol.com/coronavirus-alphabetgoogle-financial-outlook (accessed 11 November 2020).

Microsoft. (2020) Earnings Release FY20 Q3. Available at: //www.microsoft.com/en-us/Investor/earnings/ FY-2020-Q3/press-release-webcast (accessed 11 November 2020).

Protalinski E. (2020) Amazon Reports \$75.5 Billion in Q1 2020 Revenue: AWS Up 33\%, Subscriptions Up 28\%, and 'Other' Up 44\%. Venture Beat. Available at: https://wp.me/p8wLEc-aUgx (accessed 11 November 2020).

Roose K., Dance G. (2020) The Coronavirus Revives Facebook as a News Powerhouse. The New York Times. Available at: https://www.nytimes.com/2020/03/23/technology/coronavirus-facebook-news.html (accessed 11 November 2020).

Schöning F. (2019) Michele Farquhar and Peter Watts, A Turning Point for Tech. Global Survey on Digital Revolution. Hogan Lovells. Available at: https://www.hoganlovells.com/en/publications/a-turning-point-fortech-global-survey-on-digital-regulation (accessed 11 November 2020).

Scott M. (2020) How Google and Apple Outflanked Governments in the Race to Build Coronavirus Apps. Politico. Available at: https://www.politico.eu/article/google-apple-coronavirus-app-privacy-uk-france-germany (accessed 11 November 2020).

Stevens P. Here Are the 10 Companies with the Most Cash on Hand. CNBC. Available at: https://www.cnbc. com/2019/11/07/microsoft-apple-andalphabet-are-sitting-on-more-than-100-billion-in-cash.html (accessed 11 November 2020). 
Stolton S. (2020) Digital Brief, Powered by Facebook: Could Digital Tax Return to the EU? Euractiv. Available at: https://www.euractiv.com/section/digital/news/digital-brief-powered-by-facebook-could-digital-taxreturn-to-the-eu/1459700 (accessed 11 November 2020).

US Trade Representative. (2019a) Conclusion of USTR's Investigation Under Section 301 into France's Digital Services Tax. Available at: https://ustr.gov/node/10052 (accessed 11 November 2020).

US Trade Representative. (2019b) Report on France's Digital Services Tax. Available at: https://ustr.gov/sites/ default/files/Report_On_France\%27s_Digital_Services_Tax.pdf (accessed 11 November 2020).

Waters R. (2020) Big Tech Has the Cash to Expand After Crisis. Financial Times. Available at: https://on.ft. com/3ddq7hL (accessed 11 November 2020).

Wigglesworth R. (2020) How Big Tech Got Even Bigger in the Covid-19 Era. Financial Times. Available at: https://on.ft.com/3aYaEQ9 (accessed 11 November 2020).

Zara C. (2020) Amazon Stock Clobbered as Jeff Bezos Outlines COVID-19 Impact, Tells Investors to 'Take a Seat'. Fast Company. Available at: https://www.fastcompany.com/90499642 https://on.ft.com/3aYaEQ9 (accessed 11 November 2020). 